Tomasz Gutowski

Uniwersytet Gdański

\title{
Zmiany w przedsiębiorstwie wobec procesu globalizacji
}

\section{Globalizacja jako czynnik rozwoju}

Funkcjonowanie gospodarki światowej, a w jej ramach - działalność przedsiębiorstw - zarówno w ostatnim dziesięcioleciu XX w., jak i obecnie podlega gwałtownym zmianom. Jedną z przyczyn takiego stanu jest postępujący proces globalizacji gospodarki światowej oraz zawierające się w tym procesie takie zjawiska, jak: postęp nauki, techniki, organizacji i zarządzania, skracanie czasu i przestrzeni, międzynarodowa współzależność, integracja krajów, gospodarek i samych przedsiębiorstw, regionalizacja oraz rozszerzający się zakres międzynarodowej działalności przedsiębiorstw (Żurek 2002).

Powszechne jest przekonanie, iż proces globalizacji to zjawisko nowe, związane z obecnie funkcjonującą gospodarką i przedsiębiorstwami, które w tej gospodarce prowadzą swoją działalność. Pojęcie globalizacji definiowane jest jednak w różny sposób, a charakterystyka tego procesu przedstawiana przez autorów publikacji naukowych także bywa różna. Biorąc pod uwagę określenie procesu globalizacji jedynie w znaczeniu ekonomicznym, za najbardziej syntetyczne można uznać stanowisko przedstawione przez A. Zorską, która twierdzi, iż: ,globalizacja działalności gospodarczej jest to dokonujący się na świecie długofalowy proces integrowania coraz większej liczby krajowych gospodarek ponad ich granicami, dzięki rozszerzaniu oraz intensyfikowaniu wzajemnych powiązań (inwestycyjnych, produkcyjnych, handlowych, kooperacyjnych), w wyniku czego powstaje ogólnoświatowy system ekonomiczny o dużej współzależności i znaczących reperkusjach działań podejmowanych/toczących się nawet w odległych krajach” (Zorska 1998). Według K. Kucińskiego, pod pojęciem globalizacja rozumie się „ogólnoświatowy proces integracji systemów ekonomicznych i podmiotów gospodarczych. Polega on na tym, że działalność gospodarcza jest konfigurowana i koordynowana w skali całego świata w celu zminimalizowania kosztów, maksymalizowania nowo tworzonej wartości produktów i uzyskania dostępu do rynku o również światowym zasięgu. Konsekwencją, a zarazem przyczyną globalizacji gospodarki jest globalizacja wszelkich przejawów życia społecznego. Jej przejawem jest globalizacja technologii, stylu życia, modeli konsumpcji, kultury, rządzenia, regulacji prawnych, postrzegania i świadomości. Wynika ona z kompresji świata uzyskanej dzięki postępowi technicznemu i ujednolicaniu się form organizacji gospodarki oraz życia politycznego w poszczególnych krajach” (Kuciński 2002, s. 136). $\mathrm{Z}$ takiego stanowiska wynika ponadto fakt swoistego przenikania zjawiska globalizacji przez różne dziedziny. Można więc mówić o globalizacji np. w odniesieniu do polityki czy też działalności społecznej i kulturowej.

Analizując zagadnienie globalizacji, można potwierdzić, iż proces ten od początku był postrzegany raczej jako pozytywny. Poprzez dekolonizację, wiążącą się z ogłaszaniem przez 
kolejne państwa niepodległości, oraz przez powstające organizacje międzynarodowe, których zadaniem było podejmowanie działań wyrównujących dysproporcje między krajami o różnym stopniu rozwoju gospodarczego, globalizacja „rozwijała się” i oddziaływała na wszystkie sfery życia gospodarczego. W późniejszym okresie powstające organizacje międzynarodowe, tj. Układ Ogólny w Sprawie Taryf Celnych i Handlu (GATT), Europejska Wspólnota Gospodarcza (EWG), Europejskie Stowarzyszenie Wolnego Handlu (EFTA) czy Organizacja Współpracy Gospodarczej i Rozwoju (OECD) miały również sprzyjać rozwojowi tego procesu. Jednym z celów tych instytucji było - tak ważne dla funkcjonowania przedsiębiorstw - wprowadzenie ułatwień w zakresie handlu międzynarodowego poprzez znoszenie lub ograniczanie barier celnych (Bożyk, Mijała, Puławski 1999). Działania te od wielu lat przyczyniają się do zwiększenia wymiany handlowej między przedsiębiorstwami i powodują, że stają się one bardziej konkurencyjne na rynku, mając możliwość dostępu do nowoczesnych technologii oraz stosowania skutecznych metod w zakresie organizacji i zarządzania. Rozpatrując różne aspekty procesu globalizacji, warto wspomnieć o zwiększającej się w poszczególnych krajach wartości bezpośrednich inwestycji zagranicznych. Stały się one motorem procesów globalizacyjnych i w bezpośredni sposób wpłynęły na szybszy wzrost gospodarczy krajów, w sposób pośredni przyczyniły się zaś do poprawy standardów życiowych, wzrostu innowacyjności przedsiębiorstw oraz umożliwiły im ekspansję międzynarodową (Wyrwa 2006).

W gospodarkach poszczególnych krajów tempo zjawiska globalizacji nie jest jednakowe. Wynikać to może m.in. z niskiego poziomu rozwoju gospodarczego kraju lub też braku odpowiedniej infrastruktury technicznej, niezbędnej do inicjacji tego procesu. Barierami opóźniającymi rozwój gospodarki globalnej są ponadto występujące w niektórych państwach bariery prawne, polityczne i ekonomiczne. Wpływ na uczestnictwo w gospodarce globalnej niektórych państw ma również ich położenie geograficzne względem rynków zbytu, kapitału i technologii (Kuciński 2002). Funkcjonowanie współczesnego rynku światowego nie jest zatem możliwe bez zachodzących na coraz większą skalę procesów integracji ekonomiczno-społecznej. Procesy te zachodzą w sferze wymiany handlowej, ścisłej współpracy przedsiębiorstw i rządów, w sferze finansowej, we wzajemnym przenikaniu się kultur i zwyczajów oraz upodabnianiu się instytucji społecznych. Tym samym tworzy się nowe międzynarodowe środowisko, zwane globalnym, w którym funkcjonują przedsiębiorstwa wywierające różny wpływ na gospodarkę.

\section{Istota globalnej gospodarki}

Wydaje się, że rozważania dotyczące samych przedsiębiorstw nie byłyby kompleksowe bez podjęcia próby zdefiniowania gospodarki, w ramach której funkcjonują. W literaturze spotkać można wiele różnorodnych określeń. Wiele z nich nie różnicuje pojęć gospodarki światowej oraz gospodarki globalnej, utożsamiając je ze sobą. Nie są to jednak zagadnienia równoznaczne. P. Bożyk twierdzi, że gospodarka światowa to historycznie ukształtowany i zmieniający się w czasie system powiązań produkcyjnych, technologicznych, handlowych, finansowych i instytucjonalnych między gospodarkami narodowymi różnych krajów, o różnych poziomach rozwoju gospodarczo-społecznego, włączający je w ogólnoświatowy proces produkcji i wymiany (Bożyk 1991). Zwłaszcza określenie „ogólnoświatowy proces produkcji i wymiany” skłania do częstego, zamiennego używania pojęć gospodarka światowa i gospodarka globalna. Nie jest to jednak właściwe zrozumienie obu tych zagadnień. Należy zwrócić uwagę na występujące między nimi różnice. Jedną z nich jest fakt, iż pojęcie gospodarka światowa używane jest z reguły do opisu zachowań „dużego agregatu ekonomicznego w skali ogólnoświatowej, 
w skład którego wchodzą poszczególne gospodarki narodowe" (Bożyk 1991). Określenie gospodarki globalnej jest używane do podkreślenia organicznej całości światowych procesów ekonomicznych, które są nie tylko sumą poszczególnych części, ale wykazują pewne wspólne cechy dla zachowań całościowych. „Pojęcie gospodarka globalna jest więc zbliżone do określenia gospodarka narodowa, które również stosujemy, nie tyle dla przedstawienia cech agregatu, co organizmu ekonomicznego, mającego pewne prawidłowości zachowań całościowych" (Bożyk 1991).

Gospodarkę globalną w odróżnieniu od gospodarki światowej należy więc rozumieć jako system coraz ściślej powiązanych ze sobą na skutek globalizacji gospodarek narodowych. Takie określenie gospodarki globalnej pozwala na ukazanie tego pojęcia zarówno w odniesieniu do gospodarek poszczególnych państw, jak i w szczególności do podmiotów gospodarki, czyli przedsiębiorstw. Ich zadaniem w ramach gospodarki globalnej jest wytwarzanie dóbr i usług, a także ich dystrybucja oraz konsumpcja (Kuciński 2002). Z takiego stanowiska wynika fakt, iż o sile gospodarki globalnej stanowią przedsiębiorstwa zlokalizowane w różnych częściach świata.

Warto również zauważyć, że podstawą gospodarki globalnej nie są tylko przedsiębiorstwa, lecz również przepływ środków pieniężnych, towarów i usług oraz migracja osób, przepływ informacji i pomysłów. Czynniki te stanowią bardzo ważne elementy gospodarki i przyczyniają się do jej rozprzestrzeniania na gospodarki narodowe innych krajów. Szczególną uwagę należy przypisać swobodnemu, niczym nieograniczonemu przepływowi informacji. Przekazywanie informacji pomiędzy państwami, gospodarkami czy też przedsiębiorstwami przyczynia się w największym stopniu do rozwoju gospodarki globalnej. Przekazywanie informacji o nowych technologiach, sposobach wykorzystania ograniczonej ilości zasobów czy też rozwiązaniach w dziedzinie zastosowania określonych wyrobów i usług powoduje rozwój samych przedsiębiorstw. W konsekwencji prowadzi do redukcji kosztów funkcjonowania, a tym samym przyczynia się do stabilizacji działań przedsiębiorstwa.

Kolejnym, nie mniej ważnym elementem gospodarki globalnej jest czas. Wraz z jego upływem wzrasta natężenie, zakres i stopień skomplikowania zarówno przepływów pieniężnych, jak i dóbr materialnych, usług oraz informacji. Taki stan prowadzi do zrastania się narodowych rynków oraz przekształcania ich w rynki globalne. Wzrost wielkości rynków globalnych pociąga za sobą m.in. spadek zależności od państw narodowych. Formułuje się ponadnarodowa organizacja produkcji, wymiany i konsumpcji. Gospodarka globalna jest kształtowana również przez integrację regionalną, w ramach której realizowana jest szeroka współpraca w sferze politycznej i gospodarczej państw zlokalizowanych niedaleko siebie. Celem integracji regionalnej jest aktywizacja tych regionów, między którymi możliwy jest swobodny przepływ siły roboczej, kapitału, towarów, usług i informacji. Pozwala to ponadto na ochronę przestrzeni gospodarczej współpracujących ze sobą krajów. Taka wspólnota - jak dowodzi K. Kuciński posiada znamiona organizmu państwowego. Doskonałym przykładem globalizacji gospodarki w ramach integracji regionalnej jest Unia Europejska, jej wspólny rynek, waluta, polityka gospodarcza oraz parlament.

Z przytoczonych rozważań po raz kolejny wyraźnie wyłania się obraz funkcjonowania współczesnego globalnego rynku. Jak trafnie potwierdza W. Michalak, gospodarki wielu krajów świata są niejako wciągane w ogólnoświatowy system, który jest powiązany poprzez ścisłe związki kapitałowe i produkcyjno-handlowe. Ostatecznie sytuacja taka powoduje zwiększenie siły zależności krajowych gospodarek, które przenikają się wzajemnie i których struktura zmienia się pod wpływem międzynarodowej działalności gospodarczej. 


\section{Uwarunkowania rozwoju przedsiębiorstw w gospodarce globalnej}

Gospodarka globalna, oprócz powiązanego ze sobą ogólnoświatowego systemu, to przede wszystkim przedsiębiorstwa. To od nich w dużym stopniu zależy, czy system ten funkcjonuje efektywnie oraz czy podejmowane działania przekładają się na ich prawidłowy rozwój. Funkcjonowanie i systematyczny wzrost przedsiębiorstwa rozpoczyna się od odpowiedniego wyznaczenia celów jego działalności. Jak pisze J. Żurek, cele muszą być ściśle powiązane z tendencjami $\mathrm{w}$ otoczeniu międzynarodowym i krajowym oraz $\mathrm{z}$ wewnętrznymi celami przedsiębiorstwa (Żurek 2007). Osiągane przez przedsiębiorstwo wyniki finansowe, zwiększanie poziomu zatrudnienia, notowane na rynku sukcesy w zakresie wprowadzenia nowych produktów lub usług to tylko niektóre $\mathrm{z}$ czynników, które w bezpośredni sposób wpływają z jednej strony na jego rozwój, z drugiej zaś - przekładają się na rozwój gospodarczy kraju lub regionu. Rozwój przedsiębiorstwa uzależniony jest więc zarówno od czynników zewnętrznych, jak i wewnętrznych. Uwarunkowania zewnętrzne sklasyfikować można jako:

- elementy otoczenia krajowego,

- elementy otoczenia międzynarodowego.

W obu grupach mogą występować następujące uwarunkowania: ekonomiczne, ekologiczne, techniczno-technologiczne, prawne, polityczne, demograficzne oraz socjokulturowe. W grupie elementów otoczenia krajowego mają one wymiar krajowy, natomiast w drugiej grupie - charakter międzynarodowy (tab. 1).

Tab. 1. Uwarunkowania zewnętrzne prowadzenia działalności gospodarczej

\begin{tabular}{|c|c|}
\hline \multicolumn{2}{|c|}{ Uwarunkowania zewnętrzne } \\
\hline elementy otoczenia krajowego & elementy otoczenia międzynarodowego \\
\hline $\begin{array}{l}\text { - sytuacja gospodarcza (m.in. poziom i tempo } \\
\text { wzrostu PKB) } \\
\text { - polityka pieniężno-kredytowa } \\
\text { - polityka fiskalna } \\
\text { - rozwój rynku kapitałowego } \\
\text { - sytuacja społeczno-ekonomiczna } \\
\text { - poziom i tempo inflacji } \\
\text { - regulacje prawne } \\
\text { - skala i zakres interwencjonizmu państwowego } \\
\text { - wzrost popytu wewnętrznego ze strony } \\
\text { przedsiębiorstw } \\
\text { - rozwój handlu zagranicznego } \\
\text { - stan oraz kierunki rozwoju techniki } \\
\text { i technologii } \\
\text { - stan podstawowej, ogólnodostępnej } \\
\text { infrastruktury technicznej } \\
\text { - konkurencja ze strony przedsiębiorstw } \\
\text { - pozycja związków zawodowych } \\
\text { - zachowanie się władz samorządowych } \\
\text { - stan i rozwój badań naukowych }\end{array}$ & $\begin{array}{l}\text { - sytuacja polityczno-społeczna } \\
\text { - tempo wzrostu gospodarki światowej } \\
\text { - polityka gospodarcza państw i ugrupowań } \\
\text { integracyjnych } \\
\text { - stan koniunktury na rynku światowym } \\
\text { - skala interwencjonizmu i jego zakres } \\
\text { - rozwój handlu światowego i zmiany w jego } \\
\text { strukturze } \\
\text { - konkurencja na rynku światowym } \\
\text { - zmiany w strukturach organizacyjnych } \\
\text { i systemach zarządzania } \\
\text { - postęp techniczny i technologiczny } \\
\text { - postęp ekologiczny } \\
\text { - międzynarodowe regulacje prawne } \\
\text { - prognozy rynkowe }\end{array}$ \\
\hline
\end{tabular}

Źródło: Żurek J., Przedsiębiorstwo w systemie społeczno-gospodarczym [w:] Przedsiębiorstwo. Zasady działania, funkcjonowanie, rozwój, red. J. Żurek, Fundacja Rozwoju Uniwersytetu Gdańskiego, Gdańsk 2007, s. 62-63. 
Siła oddziaływania poszczególnych czynników na podmiot gospodarczy może być różna. Zależy ona m.in. od wielkości przedsiębiorstwa, formy prawnej prowadzenia działalności gospodarczej, zakresu działalności oraz przyjętej przez przedsiębiorstwo strategii. Wydaje się jednak, że w przypadku przedsiębiorstwa funkcjonującego na rynku lub wielu rynkach zagranicznych czynniki otoczenia zewnętrznego, zarówno w układzie krajowym, jak i międzynarodowym, będą silniej determinowały jego funkcjonowanie i rozwój.

Oprócz czynników o charakterze zewnętrznym na funkcjonowanie przedsiębiorstwa wpływają również czynniki wewnętrzne. K. Bolesta-Kukułka, przedstawiając ujęcie organizacji jako systemu społeczno-technicznego, zalicza do nich następujące elementy (podsystemy): cele i zadania, ludzie (pracownicy przedsiębiorstwa), struktura formalna, wyposażenie oraz technika i technologia (Bolesta-Kukułka 1995). Elementy te wymagają jednak uszczegółowienia. I tak - cele i zadania przedsiębiorstwa to m.in. misja, cele strategiczne, taktyczne i operacyjne oraz zadania realizowane w przedsiębiorstwie przez pracowników, których z kolei motywacje, przyzwyczajenia, postawy kwalifikacje, umiejętności, energia, zdolność uczenia się oraz stosunki międzyludzkie mogą być różne (Wajda 2003). Do struktury formalnej przedsiębiorstwa zaliczyć należy hierarchię, schemat organizacyjny obowiązujący w przedsiębiorstwie, zakresy czynności jego pracowników oraz instrukcje. Wyposażenie i technika to zaś „zbiór ogólnych i szczegółowych sposobów, technik oraz narzędzi służących realizacji organizacyjnych zadań” (Bolesta-Kukułka 1995).

Do elementów wewnętrznych, odgrywających zasadniczą rolę w rozwoju współczesnego przedsiębiorstwa, zaliczyć należy ponadto zasoby materialne w postaci budynków, maszyn, urządzeń, a także wartości niematerialne i prawne. Prowadząc rozważania nad nowymi, współczesnymi zasobami przedsiębiorstwa, należy zwrócić szczególną uwagę na niespotykane wcześniej w przedsiębiorstwie dowartościowanie zasobów niematerialnych i prawnych, tj. licencje, nieopatentowane wynalazki, wzory użytkowe, patenty czy know-how ${ }^{1}$. Suszyński pisze ponadto, że ,produkty wiedzy, takie jak nowoczesne technologie, a także renoma, marka, tożsamość przedsiębiorstwa, charyzmatyczne przywództwo, oryginalna strategia czy wiele innych podobnych stały się aktywami, a wręcz właściwościami przedsiębiorstwa niezbędnymi w walce o rynek" (Suszyński 2007). Wspólnie z innymi stają się one elementami wpływającymi bardzo dynamicznie na rozwój przedsiębiorstwa. Przekładają się w wyraźny sposób na budowanie konkurencyjności podmiotów gospodarczych na coraz bardziej zglobalizowanym rynku.

Kolejnym, często pomijanym w literaturze czynnikiem o charakterze wewnętrznym, współtworzonym przez nowe zasoby przedsiębiorstwa, jest jego kultura organizacyjna. Definiowana jako pewien zbiór wartości, norm społecznych i tradycji akceptowanych przez członków danego przedsiębiorstwa, może stać się elementem pozytywnie wpływającym na dotychczas

\footnotetext{
${ }^{1}$ Definicja przyjęta przez Międzynarodową Izbę Handlową w Paryżu jako know-how określa całokształt wiadomości, czyli fachowej wiedzy oraz doświadczeń w zakresie technologii i procesu produkcyjnego dla określonego wyrobu. W prawie europejskim definicja know-how zawarta jest w Rozporządzeniu nr 772/2004 w sprawie stosowania art. 81 ust. 3 „, Traktatu do kategorii porozumień o transferze technologii" (Dz.U. L 123 z 27.4.2004, s. 11-17). Stanowi ona, iż know-how to pakiet nieopatentowanych informacji praktycznych wynikających z doświadczenia i badań, które są: niejawne, czyli nie są powszechnie znane lub łatwo dostępne, istotne, czyli ważne i użyteczne z punktu widzenia wytwarzania produktów objętych umową, oraz zidentyfikowane, czyli opisane w wystarczająco zrozumiały sposób, aby można było sprawdzić, czy spełniają kryteria niejawności i istotności. Źródło: http://pl.wikipedia.org/wiki/Know-how (11.10.2010); Suszyński C. (red.), Przedsiębiorstwo. Wartość. Zarządzanie, PWE, Warszawa 2007.
} 
obowiązującą strukturę organizacyjną podmiotu. W innym przypadku kultura organizacyjna może okazać się istotną przeszkodą w funkcjonowaniu przedsiębiorstwa i przez to w negatywny sposób oddziaływać na jego bieżące funkcjonowanie i rozwój w przyszłości.

\section{Ważność zasobów przedsiębiorstwa dla jego rozwoju}

Interesujące stanowisko przedstawiające oddziaływanie procesu globalizacji przedstawia C. Suszyński. Formułuje on trzy następujące „,wnioski w odniesieniu do samego przedsiębiorstwa:

- przez globalizację tworzy się nowa jakość mechanizmu rynku, który kreuje dla coraz większej grupy jego uczestników wyzwania szersze, wręcz cywilizacyjne, a więc stawia im wymagania na poziomie i o intensywności, jakich wcześniej nie doświadczali,

- sprostanie tym wyzwaniom (alokacja zasobów, dystrybucja efektów) prowadzi do daleko idących zmian podstaw wyodrębnienia (podmiotowości) i funkcjonowania przedsiębiorstw oraz oceny rezultatów prowadzonej przez nie działalności,

- wśród najważniejszych czynników owego wyodrębnienia, funkcjonowania i oceny przedsiębiorstw istotne miejsce zajmują kryteria i wartości szerzej, wręcz globalnie akceptowane (np. wartość dla klienta, wartość dla akcjonariusza” (Suszyński 2007, s. 53).

To właśnie przedsiębiorstwo narażone jest na konieczność dostosowania się do wymogów współczesnej gospodarki. Stopień dostosowania może świadczyć o osiągnięciu przez nie określonego poziomu konkurencyjności, a także wpływać na bieżące funkcjonowanie oraz tempo jego rozwoju w przyszłości.

Zasadniczym kierunkiem rozwoju współcześnie funkcjonującego podmiotu gospodarczego jest dążenie przedsiębiorstwa do osiągania przewagi konkurencyjnej i zwiększenia własnej konkurencyjności. W ramach przewagi konkurencyjnej na pierwszy plan wysuwa się problematyka zasobów przedsiębiorstwa. W dążeniach do sprostania wymogom czasu ulegają one istotnym przewartościowaniom. Jak pisze C. Suszyński: „Jednym z bardziej znaczących zjawisk w okresie ostatnich kilku dekad, o doniosłym w skutkach w wymiarze poznawczym [...], ale przede wszystkim mającym głębokie przełożenia na sferę praktyki gospodarczej, okazało się niespotykane wcześniej dowartościowanie zasobów niematerialnych. [...] «Produkty» wiedzy, takie jak nowoczesne technologie, a także renoma, marka, tożsamość przedsiębiorstwa, charyzmatyczne przywództwo, oryginalna strategia czy wiele innych podobnych stały się aktywami, a wręcz właściwościami przedsiębiorstwa niezbędnymi w walce o rynek" (Suszyński 2007).

W dobie tzw. społeczeństwa informacyjnego nie należy zapominać również o kolejnym elemencie przyczyniającym się do rozwoju przedsiębiorstwa, jakim jest wiedza i informacja. Zdolność do ich zdobywania, analizy oraz umiejętność przekazywania osobom zatrudnionym w przedsiębiorstwie jest niezbędnym czynnikiem rozwoju podmiotu na globalnym rynku. $\mathrm{Z}$ jednej strony przyczyniają się one do lepszego zrozumienia otoczenia zewnętrznego, jego specyfiki i stopnia skomplikowania, z drugiej zaś - są niezbędne do podejmowania bieżących decyzji, dotyczących na przykład możliwości efektywnego stosowania w przedsiębiorstwie nowoczesnych technologii. Pojęcie technologii we współczesnej gospodarce ma jednak inny wymiar, niż miało to miejsce przed laty. Jak dowodzi J. Witkowska: „technologia, rozumiana w szerokim sensie, obejmuje wiedzę menedżerską, umiejętności marketingowe oraz inne tzw. nieuchwytne aktywa na poziomie firmy" (Witkowska 2005, s. 33). Rozprzestrzenianie się tak rozumianej technologii wśród wielu przedsiębiorstw powoduje, iż jest ona czynnikiem transnarodowym i poprzez to czynnikiem rozwoju przedsiębiorstw na całym świecie. Proces globalizacji, którego efektem jest upodabnianie się do siebie narodowych gospodarek i całych społeczeństw, zacieranie się granic, ujednolicenie ogólnych wzorców konsumpcji w konsekwencji powodują nasilenie przenikania wiedzy i informacji, które z kolei stanowią o istocie wielu 
innowacji. Faktycznie to właśnie one są końcowym efektem transferu wiedzy i informacji we współczesnej gospodarce. Poziom ważności innowacji w przedsiębiorstwach nie podlega dyskusji. Często stosuje się pojęcie polityki innowacyjnej przedsiębiorstwa, czyli takiego działania, którego celem, w ściśle określonym czasie, ma być wdrożenie określonej innowacji w przedsiębiorstwie i uzyskanie dzięki temu możliwości szybszego rozwoju w porównaniu z konkurencją.

\section{Konkurencyjność podmiotu gospodarczego}

Osiąganie przez przedsiębiorstwo sukcesu rynkowego jest zagadnieniem niezwykle interesującym, lecz nie zawsze jednoznacznym. $Z$ jednej strony sukces przedsiębiorstwa definiuje się głównie według pozycji, jaką udało mu się zając w dziedzinie prowadzonej działalności. Jeśli na przykład osiąga ono dobre wyniki finansowe i przewyższa swoich konkurentów pod względem jakości, to dzieje się tak dlatego, że dysponuje zasobami i kompetencjami, które umiało sobie wypracować i zastosować w dobrze wybranej dziedzinie działalności (Kotler 1999). $Z$ drugiej zaś strony czasami sukcesem przedsiębiorstwa może być same jego utrzymanie się na coraz bardziej konkurencyjnym rynku. Przy znacznie zmniejszonej skali obrotów i obniżanych corocznie wynikach finansowych, będących jednymi z negatywnych efektów zwiększającej się liczby i jakości konkurentów, myślenie o zdobywaniu lepszej pozycji nie jest możliwe. Z czasem oczywiście sytuacja ta może ulec zmianie, ale w takich warunkach sukces przedsiębiorstwa pojmowany jest zupełnie odmiennie.

Stwierdzić można, że sukces przedsiębiorstwa we współczesnej gospodarce ma swoje źródło zarówno w bieżącym, stabilnym funkcjonowaniu podmiotu gospodarczego, jak również a może przede wszystkim - w jego rozwoju. Wyzwania współczesnego rynku, związane z przebiegiem i rozwojem procesu globalizacji, stwarzają przedsiębiorstwu wiele szans rozwojowych. Stawiają jednak również przed nim wiele zagrożeń, których dynamika jest tak gwałtowna, że znacznie utrudnia lub wręcz uniemożliwia funkcjonowanie podmiotu gospodarczego. Receptą na pewne uniezależnienie się od tych gwałtownych zmian i możliwość odniesienia sukcesu rynkowego jest - wspomniane wcześniej - dążenie do wzrostu konkurencyjności przedsiębiorstw. W teorii ekonomii oraz prowadzonych badaniach empirycznych nie ma zgodności dotyczącej zdefiniowania pojęcia konkurencyjności. W definiowaniu tego zjawiska można spotkać się ze stwierdzeniem, iż jest to pojęcie teoretyczne oraz stan odnoszący się do sfery działalności instytucji rynkowych. Dla istnienia konkurencyjności niezbędny jest rynek, natomiast ona sama jest „,echą i mechanizmem regulującym zachowania podmiotów na rynku” (Roszyk-Kowalska 2007, s. 4). Stwierdzić zatem można, że konkurencyjność nie może być rozpatrywana niezależnie od rynku. Zagadnienie to w bezpośredni sposób dotyczy wszystkich przedsiębiorstw funkcjonujących na tym rynku.

Przedstawiając definicję konkurencyjności, H. Adamkiewicz podaje, że: „Pod pojęciem konkurencyjności przedsiębiorstwa rozumie się właściwość, która określa jego zdolność do ciągłego kreowania tendencji rozwojowej, wzrostu produktywności [...] oraz do skutecznego rozwijania rynków zbytu w warunkach oferowania przez konkurentów towarów lub/i usług nowych, lepszych i tańszych" (Adamkiewicz 2001, s. 1). Jak dowodzą A. Oniszczuk-Jastrząbek i T. Gutowski: „W tej definicji podkreśla się, że omawiane pojęcie konkurencyjności jest ściśle związane z oferowaniem przez przedsiębiorstwo produktu, lepszego pod względem jakości, ceny czy też bardziej funkcjonalnego, niż produkt oferowany klientowi przez innych konkurentów. [...] nie jest to jednak definicja pełna. Oprócz poziomu jakości oferowanego produktu, jego ceny, czy też funkcjonalności [...] zwrócić należy również uwagę na inne czynniki, przyczyniające się do zwiększenia konkurencyjności podmiotów gospodarczych" (Oniszczuk- 
-Jastrząbek, Gutowski 2007, s. 179). Stąd też określenie konkurencyjności, jako umiejętności skutecznego konkurowania przedsiębiorstw na rynku, a więc skutecznego funkcjonowania i rozwoju w konkurencyjnym otoczeniu wydaje się najbardziej trafne (Gorynia 2002; Oniszczuk-Jastrząbek, Gutowski 2007). Pojęcie konkurencyjność można również rozumieć jako agregat złożony z następujących elementów (Rybak 2003, s. 11):

- potencjału konkurencyjności,

- przewagi konkurencyjnej,

- instrumentów konkurowania,

- pozycji konkurencyjnej sprzedającego.

Między tymi elementami zachodzą relacje przyczynowo-skutkowe, co oznacza, że zmiana jednego z tych elementów powoduje zmianę innego.

Ryc. 1. Struktura konkurencyjności przedsiębiorstwa

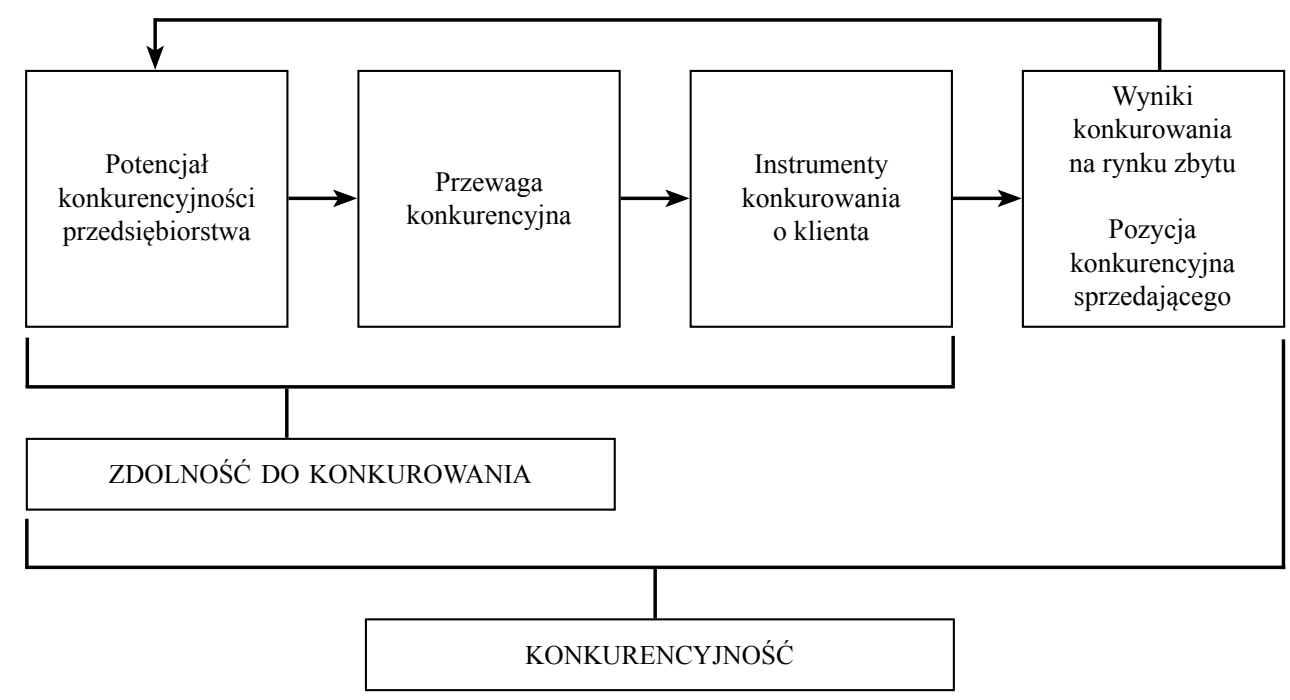

Źródło: opracowanie własne na podstawie Stankiewicz 2000, s. 79.

Jednoczesne zmiany poszczególnych elementów - potencjału konkurencyjności przedsiębiorstwa, przewagi konkurencyjnej oraz instrumentów konkurowania o klienta - wpływają na osiągnięcie przez przedsiębiorstwo określonego poziomu zdolności do konkurowania.

W takim rozumieniu tego pojęcia potencjał konkurencyjności przedsiębiorstwa to możliwość jego skutecznego funkcjonowania na rynku (Otta 1988). Pod tym pojęciem rozumie się również system zasobów materialnych i niematerialnych umożliwiających przedsiębiorstwu budowanie przewagi konkurencyjnej (Godziszewski 1999). Zależy on m.in. od liczebności przedsiębiorstw, łącznej liczby zatrudnionych pracowników, wysokości zaangażowanego kapitału oraz od rodzajów i wielkości luk rynkowych, które przedsiębiorstwa te wypełniają swą produkcją, handlem lub oferowanymi usługami.

Przewaga konkurencyjna możliwa jest zaś do osiągnięcia w wyniku realizowanej strategii. Jej zasadniczym celem jest wytworzenie większego od średniego zysku dla branży i posiadanie znaczącego udziału w rynku. Do instrumentów konkurowania zalicza się natomiast „narzędzia i sposoby pozyskiwania klientów i dostawców w warunkach akceptowanych przez przedsiębiorstwo i służących osiąganiu jego celów” (Roszyk-Kowalska 2007, s. 3). 
W skład łańcucha konkurencyjności wchodzi ponadto pozycja konkurencyjna sprzedającego. Jak podkreśla G. Roszyk-Kowalska: „Jest to wynik oceny przez rynek (w szczególności przez nabywców) tego, co przedsiębiorstwo na nim oferuje. Oznacza ona miejsce na skali korzyści ekonomicznych i pozaekonomicznych, jakie przedsiębiorstwo dostarcza swoim interesariuszom, w porównaniu z tymi miejscami, które pod tymi samymi względami zajmują jego konkurenci. Najbardziej podstawowymi i syntetycznymi miernikami pozycji konkurencyjnej każdego przedsiębiorstwa jest jego udział w rynku oraz osiągnięta sytuacja finansowa" (Roszyk-Kowalska 2007, s. 4). Należy podkreślić, że osiągnięcie pożądanej pozycji konkurencyjnej jest uwarunkowane stanem przewagi konkurencyjnej przedsiębiorstwa.

\section{Sposoby osiągania przewagi konkurencyjnej}

Przewaga konkurencyjna przedsiębiorstwa, stanowiąca jeden z elementów struktury konkurencyjności przedsiębiorstwa, jest zagadnieniem złożonym. Często też jest pojęciem nadużywanym i mylonym z samą konkurencyjnością. Czym więc jest owa przewaga konkurencyjna, będąca często głównym pragnieniem przedsiębiorstw funkcjonujących we współczesnej gospodarce? Stwierdzić można, że przewaga konkurencyjna jest to osiągnięcie przez przedsiębiorstwo nadrzędnej pozycji wobec większej liczby konkurentów. Jest ona relatywną miarą funkcjonowania na rynku, która pozwala na zaoferowanie klientowi usług lub produktów odpowiadających jego oczekiwaniom, a lepszych niż oferty konkurencji. Wyraża się ona w wyższej jakości produktu, niższej cenie i lepszej obsłudze lub bardziej kompleksowym zaspokojeniu potrzeb klienta. W przytoczonej definicji na plan pierwszy wysuwa się zaspokojenie potrzeb klienta, jego satysfakcja, stanowiące główne czynniki osiągania przez przedsiębiorstwo przewagi konkurencyjnej. Postrzeganie usatysfakcjonowanego klienta jako zasobu przedsiębiorstwa ma nie tyle filozoficzny, co silnie ekonomiczny sens (Haffer 2000). M.E. Porter stwierdza natomiast, że zjawisko przewagi konkurencyjnej jest duszą wyników firm działających na konkurencyjnych rynkach (Porter 1985). J.B. Barney definiuje ją jako zdolność do realizowania strategii, której nie są w stanie wdrożyć aktualni i przyszli konkurenci (Barney 1991). W dwóch ostatnich przytoczonych definicjach elementem najważniejszym są przedsiębiorstwa i ich konkurenci działający na tym samym rynku. Wydaje się, że najpełniejszą definicję przewagi konkurencyjnej podaje M.J. Stankiewicz. Twierdzi on, że na tworzenie ogólnej przewagi konkurencyjnej składają się cząstkowe przewagi uzyskiwane w zakresie konkretnych ofert rynkowych. Określa ją ponadto jako zdolność do takiego wykorzystania potencjału konkurencyjności przedsiębiorstwa, jakie umożliwia na tyle efektywne generowanie atrakcyjnej oferty rynkowej i skutecznych instrumentów konkurowania, że zapewnia to powstanie wartości dodanej (Stankiewicz 2002). Widocznymi przejawami uzyskania przewagi konkurencyjnej mogą więc być między innymi następujące elementy: niższe koszty wytworzenia i wynikające stąd niższe ceny, oryginalność produktu, dobra obsługa nabywców oraz obsługa posprzedażna, poprawa organizacji sprzedaży, wyspecjalizowana oferta czy zaoferowanie klientom produktu charakteryzującego się wyższym niż u konkurencji lub wręcz niespotykanie wysokim poziomem jakości (Famielec 1997).

W literaturze spotkać można wiele różnych systematyzacji strategii osiągania przewagi konkurencyjnej oraz dużą liczbę kryteriów ich wyodrębniania. W oparciu o kryterium skali, w jakiej przedsiębiorstwo ją uzyskało lub dąży do jej uzyskania, wyróżnić można globalną oraz lokalną przewagę konkurencyjną (Stankiewicz 2002). Pierwsza z nich realizowana jest na rynkach podlegających globalnej konkurencji i dotyczy przedsiębiorstw, które na tych rynkach prowadzą działalność gospodarczą. Druga - odnosi się do podmiotów gospodarczych, których zasięg działania jest zdecydowanie mniejszy i dotyczy jedynie pewnych ściśle określonych rynków, najczęściej lokalnych czy regionalnych. 
Najbardziej powszechnym kryterium klasyfikacji przewag konkurencyjnych według kryterium ich podstawowej bazy jest propozycja M.E. Portera. Zgodnie z nią wyróżnić można trzy główne źródła i odpowiadające im typy przewag (Porter 1996):

- przewagę wynikającą z przywództwa kosztowego,

- przewagę wynikającą ze zróżnicowania (dywersyfikacji),

- przewagę wynikającą z koncentracji (skupienia).

Ryc. 2. Ogólne strategie konkurencyjne

PRZEWAGA STRATEGICZNA

\begin{tabular}{|c|c|c|c|}
\cline { 3 - 4 } \multicolumn{2}{c|}{} & $\begin{array}{c}\text { unikalność postrzegania } \\
\text { przez klienta }\end{array}$ & pozycja niskiego kosztu \\
\hline $\begin{array}{c}\text { Cele } \\
\text { strategiczne }\end{array}$ & w skali sektora & zróżnicowanie & wiodąca pozycja kosztowa \\
\cline { 2 - 4 } & $\begin{array}{c}\text { w skali } \\
\text { segmentu }\end{array}$ & \multicolumn{2}{|c|}{ koncentracja } \\
\hline
\end{tabular}

Źródło: Porter 1996, s. 54.

Każda z wymienionych strategii zakłada odmienny sposób osiągania przewagi konkurencyjnej. W przypadku strategii przywództwa kosztowego celem przedsiębiorstwa jest osiągnięcie, a następnie utrzymanie niższego niż konkurenci poziomu kosztów produkcji przy równocześnie wysokiej jej jakości. „Wiodąca pozycja pod względem kosztów wymaga inwestowania w urządzenia produkcyjne na efektywną skalę, dążenia do obniżenia kosztów poprzez zdobywanie doświadczenia, ścisłą kontrolę kosztów bezpośrednich i ogólnych, unikanie klientów o marginalnym znaczeniu, reklamy, obsługi posprzedażnej itp.” (Kotowicz-Jawor 1998, s. 22). Kolejną strategią konkurencyjną jest strategia zróżnicowania (dywersyfikacji). Jest ona stosowana wówczas, gdy przedsiębiorstwo ma do zaoferowania klientom unikatowy produkt, który będzie najwyżej przez nich ceniony. Elementami różnicowania mogą być na przykład: określona cecha produktu, system jego dostawy lub marketing (Stanieda 2006). Zwykle poprawa tych kryteriów pociąga za sobą z jednej strony konieczność poniesienia przez przedsiębiorstwo wyższych niż konkurencja kosztów, z drugiej zaś umożliwia oferowanie na rynku własnych produktów po wyższej cenie. Trzecią strategią konkurencyjną jest ta, która polega na dążeniu przedsiębiorstwa do osiąnnięcia efektów w jednym wybranym segmencie. Powszechnie jest ona nazywana strategią koncentracji (skupienia). Jej istota zakłada, że pewne „ograniczenie” do wybranego segmentu powinno powodować pełne zaspokojenie potrzeb konsumentów. Tę część rynku można bowiem obsłużyć sprawniej i skuteczniej, niż czyni to konkurencja. Tak przedstawiona charakterystyka wszystkich trzech strategii konkurencji pozwala na wyciągnięcie ogólnego wniosku dotyczącego osiągania przewagi konkurencyjnej. Jak trafnie ujmuje J. Stanienda: ,ppodstawowym warunkiem skutecznego działania [przedsiębiorstwa - T.G.] jest wyróżnienie tego elementu czy tej strefy, w których przedsiębiorstwo będzie miało przewagę nad konkurentami” (Stanieda 2006, s. 21). W związku z tym możliwe jest przyjęcie pewnych zasad warunkujących uzyskanie przewagi, czyli osiągnięcie sukcesu rynkowego. Należy być najlepszym w jednej z trzech wymienionych strategii, stale udoskonalać pozycję lidera w jednej z nich oraz poszukiwać najkorzystniejszej pozycji w pozostałych dwóch (Altkorn 2000). 
Tab. 2. Skutki działań konkurencyjnych przedsiębiorstwa

\begin{tabular}{|c|c|}
\hline $\begin{array}{l}\text { Skutki dzialań } \\
\text { konkurencyjnych }\end{array}$ & Charakterystyka skutków \\
\hline Ekonomiczne & $\begin{array}{l}\text { - ich istotą jest dążenie do tego, aby osiągnąć jak najwięcej, stworzyć } \\
\text { podstawy rozwoju, sprawnie funkcjonować i osiągać jak najwyższy zysk }\end{array}$ \\
\hline Prestiżowe & $\begin{array}{l}\text { - wyrażają się w jak najlepszej opinii, w utrwalaniu własnego stylu, } \\
\text { uzyskaniu przychylności nabywców przekonanych o dbałości o ich } \\
\text { interesy, stworzeniu korzystnych wyobrażeń o przedsiębiorstwie } \\
\text { i jego działalności }\end{array}$ \\
\hline Bieżące & $\begin{array}{l}\text { - wyrażają się w umiejętności elastycznego operowania celami, } \\
\text { celowego nasilania reklamy handlowej, umiejętności działań } \\
\text { sezonowych }\end{array}$ \\
\hline Odłożone w czasie & $\begin{array}{l}\text { - przedsiębiorstwo chce osiągnąć je nawet za cenę zmniejszonego przez } \\
\text { pewien okres dochodu lub innych zjawisk przyciągających nabywcę, } \\
\text { a pozwalających w przyszłości na osiągnięcie korzystniejszej pozycji } \\
\text { przez przedsiębiorstwo na rynku }\end{array}$ \\
\hline Strategiczne & $\begin{array}{l}\text { - polegają na budowaniu perspektyw ekspansji w danym rejonie, } \\
\text { dokonywaniu przestrzennych zmian w produkcji i obrocie, tworzeniu } \\
\text { nowych związków kapitałowych, wprowadzeniu nowych generacji } \\
\text { produktów do produkcji, obrotu itp. }\end{array}$ \\
\hline Kompleksowe & $\begin{array}{l}\text { - dotyczą całego przedsiębiorstwa i polegają na tworzeniu jego nowego } \\
\text { wizerunku, budowaniu więzi informacyjnych z nowymi odbiorcami, } \\
\text { nasilaniu innowacji w produkcji, obrocie itp. }\end{array}$ \\
\hline Całościowe & $\begin{array}{l}\text { - dotyczą konkretnego produktu i polegają na tworzeniu wyróżniającego } \\
\text { się produktu, który symbolizuje przedsiębiorstwo lub jest absolutnym } \\
\text { przebojem, dzięki czemu przedsiębiorstwo nie tylko się dynamicznie } \\
\text { rozwija, ale również ma dobrą opinię itp. }\end{array}$ \\
\hline
\end{tabular}

Źródło: opracowanie własne na podstawie Stanienda 2006, s. 21.

Nieco inaczej przewagę konkurencyjną opisuje C. Suszyński. Wychodzi on z założenia, iż przedsiębiorstwo musi posiadać i sprawnie zarządzać posiadanymi atutami, do których zalicza wszystko to, co jest lub będzie bardzo trudne do odtworzenia przez konkurencję i co stanowić będzie satysfakcję jego klientów. Głównymi atutami podmiotu gospodarczego w tym przypadku są następujące elementy:

- stosowana w przedsiębiorstwie technologia wytwarzania produktów bądź usług,

- zrozumienie zachowań rynku, gdzie dużą rolę odgrywa informacja i jej przepływ między podmiotami gospodarczymi oraz wewnątrz nich,

- know-how,

- tempo wykonywania zleconych prac,

- atrakcyjny (krótki) czas dostaw od producenta do klienta,

- możliwości wypracowania własnej marki,

- lojalność klienta lub określonej grupy klientów,

- stworzenie odpowiedniego wizerunku przedsiębiorstwa. 
Elementy te prowadzą w konsekwencji do osiągnięcia przewagi konkurencyjnej oraz przede wszystkim do wzrostu wartości dla współwłaścicieli przedsiębiorstwa. „Zdobyta przewaga konkurencyjna generuje wartość dodaną dla przedsiębiorstwa, która z kolei jest źródłem wartości dla akcjonariuszy [...]. Wynika z tego, że tworzenie wartości dla klienta odgrywa główną rolę w tworzeniu wartości dla akcjonariuszy, a cały proces zarządzania wartością rozpoczyna się od klienta i kończy na inwestorze" (Suszyński 2007, s. 64).

Ryc. 3. Współczesny model przewagi konkurencyjnej

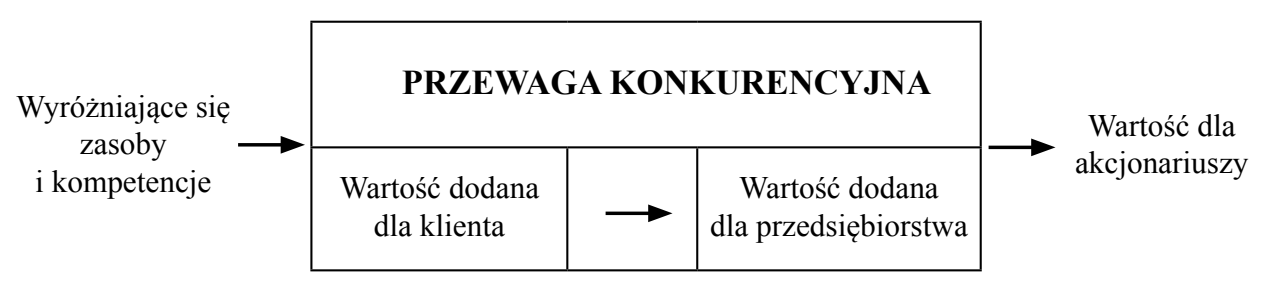

Źródło: opracowanie własne na podstawie Suszyński 2007, s. 128.

Praktycznym narzędziem służącym do określenia pozycji konkurencyjnej przedsiębiorstwa są metody analizy strategicznej firmy. Odpowiedź na pytanie, jakie działania należy podjąć w przedsiębiorstwie przy określonej atrakcyjności przemysłu i znanej pozycji konkurencyjnej, daje na przykład macierz General Electric Corporation, znana bardziej jako macierz GE lub też macierz McKinseya. W zależności od określonej „,siły” dwóch jej elementów, formułowane są na jej podstawie zalecenia strategiczne (Stabryła 2002).

Wyniki przeprowadzonej analizy dają osobom zarządzającym podmiotem gospodarczym możliwość opracowania strategii przedsiębiorstwa, której zasadniczym celem w konsekwencji będzie tworzenie wartości dla jego współwłaścicieli. Jak podkreśla P. Doyle, ocena pozycji strategicznej przedsiębiorstwa dostarcza informacji, na podstawie których może być sporządzona wycena całego przedsiębiorstwa, umożliwia identyfikację czynników determinujących wartość, przez co zachęca kierownictwo podmiotu do wdrażania nowych strategii działania (Doyle 2003).

\section{Obszary zmian w przedsiębiorstwie wobec procesu globalizacji - założenia badań własnych}

Konkurencyjność podmiotów gospodarczych funkcjonujących w Polsce, w warunkach gospodarki coraz bardziej globalnej, jest przedmiotem licznych badań. Ich autorzy, posługując się rozmaitymi metodami badawczymi, starają się zwrócić uwagę na te czynniki, które w najsilniejszy sposób mogą wpłynąć na zwiększenie konkurencyjności. Dla potrzeb badawczych autor artykułu wraz z dr A. Oniszczuk-Jastrząbek w roku 2007 i 2008 przeprowadzili - wśród polskich podmiotów gospodarczych - podobne badania ankietowe. Skupili swoją uwagę na czynnikach wynikających ze zmian w następujących sferach działalności gospodarczej: inwestycje, personel, wartości niematerialne i prawne, organizacja i zarządzanie, finanse, logistyka, produkcja, badanie i rozwój, jakość oraz marketing. Ankietowani odpowiadali na pytania związane z tymi czynnikami, określając wpływ poszczególnych elementów z tych sfer na konkurencyjność przedsiębiorstwa w skali: bardzo duży, duży, mały, bardzo mały, nie ma wpływu, nie mam zdania. W kilku przypadkach ankietowani mieli możliwość dokonania wyboru stopnia ważności kryteriów decydujących o konkurencyjności przedsiębiorstwa w warunkach globalnych. 
Wyniki przeprowadzonych badań pozwoliły na identyfikację najważniejszych sfer działalności tych podmiotów oraz na określenie pożądanych kierunków zmian w celu zwiększenia własnej konkurencyjności wobec wyzwań globalnego rynku. W znacznej części przypadków respondenci, mimo dążenia do rozwoju własnej działalności, w niewielkim stopniu dostrzegali proces globalizacji gospodarki. Zwracali uwagę na kilkadziesiąt czynników, które ich zdaniem mogłyby wpłynąć znacząco na wzrost ich konkurencyjności. Wielu wykazywało jednak bardzo dużą wiarę we własne dotychczas stosowane działania i nie zauważało jakichkolwiek zagrożeń związanych z wyzwaniami współczesnego rynku. Jednym z głównych wniosków było zwrócenie uwagi na fakt, iż brak działań dostosowawczych może w krótszym okresie czasu prowadzić do marginalizacji przedsiębiorstwa, a w dłuższym - przyczynić się do jego upadłości bądź likwidacji. W ubiegłym roku prowadzone były kolejne badania ankietowe, a ich zakończenie nastąpiło z końcem listopada $2010 \mathrm{r}$. Autorzy - mając doświadczenia z lat poprzednich - postanowili dokonać m.in. uszeregowania kryteriów decydujących o konkurencyjności podmiotu gospodarczego oraz oceny wpływu czynników na konkurencyjność. Osobne pytania dotyczyły innowacyjności przedsiębiorstwa, a odpowiedź na nie umożliwiła poznanie źródeł innowacji oraz określenie jej miejsca w rozwoju przedsiębiorstwa. Autorzy przeprowadzili również wśród kilkuset polskich przedsiębiorstw kampanię informacyjną o prowadzonych badaniach. Ankieta została umieszczona na serwerze Wydziału Ekonomicznego Uniwersytetu Gdańskiego ${ }^{2}$.

Funkcjonowanie gospodarki globalnej, a w jej ramach - oddziaływanie procesu globalizacji na działalność przedsiębiorstw - jest bezsprzeczne. Przedsiębiorstwa, chcąc prowadzić skuteczną walkę konkurencyjną z innymi uczestnikami rynku zmuszone są do przeprowadzenia odpowiednich działań adaptacyjnych. Zadania te mogą być realizowane w wielu obszarach działalności gospodarczej, a ich realizacja może zależeć zarówno od działań samego przedsiębiorstwa, jak i tego, co rozgrywa się w jego otoczeniu.

Warto zatem prowadzić ciągły monitoring działań związanych z rozwojem współczesnego przedsiębiorstwa i cały czas zastanawiać się na tym, co z rozważań teoretycznych na temat konkurencyjności można przełożyć na konkretne działanie.

\section{Literatura}

1. Adamkiewicz H.G., 2001, Adaptacja rynkowa jako istotny czynnik strategiczny osiagnięcia sukcesu przez przedsiębiorstwo w warunkach globalizacji [w:] Prace Naukowe Katedry Zarządzania, Wydawnictwo Wyższej Szkoły Morskiej, Gdynia.

2. Altkorn J., 2000, Wyróżniki tożsamości przedsiębiorstwa, „Marketing i Rynek”, nr 6.

3. Barney J.B., 1991, Firm Resources and Sustained Competitive Advantage, „Journal of Management”, Vol. 17, No 1, Southern Management Association, s. 99-120.

4. Bolesta-Kukułka K., 1995, Świat organizacji [w:] Zarządzanie. Teoria i praktyka, A. Koźmiński, W. Piotrowski (red.), Wydawnictwo Naukowe PWN, Warszawa.

${ }^{2}$ Kwestionariusz ankietowy został umieszczony pod adresem: https://ekonom.ug.edu.pl/gp/ (hasło dostępu: GLOBAL). 
5. Bożyk P., 1991, Gospodarka światowa, PWE, Warszawa.

6. Bożyk P., Mijala J., Puławski M., 1999, Międzynarodowe stosunki ekonomiczne, PWE, Warszawa.

7. Doyle P., 2003, Marketing wartości, Wydawnictwo Felberg SJA, Warszawa.

8. Famielec J., 1997, Strategie rozwoju przedsiębiorstwa, Wydawnictwo Akademii Ekonomicznej, Kraków.

9. Godziszewski B., 1999, Potencjał konkurencyjności przedsiębiorstwa jako źródto przewag konkurencyjnych i podstawa stosowania instrumentów konkurowania [w:] Budowanie potencjału konkurencyjności przedsiębiorstwa, M.J. Stankiewicz (red.), Wydawnictwo TNOiK, Toruń.

10. Gorynia M., 2002, Luka konkurencyjna na poziomie przedsiębiorstwa a przystapienie Polski do Unii Europejskiej, Wydawnictwo Akademii Ekonomicznej w Poznaniu, Poznań.

11. Haffer R., 2000, Satysfakcja konsumentów i jej pomiar [w:] Marketingowe testowanie produktów, S. Sudol, J. Szymczak, M. Haffer (red.), PWE, Warszawa.

12. Kotler P., 1999, Marketing. Analiza, planowanie, wdrażanie i kontrola, Wydawnictwo Felberg SJA, Warszawa.

13. Kotowicz-Jawor J., 1998, Przebudowa mikroekonomicznego mechanizmu rozwoju, PWN, Warszawa.

14. Kuciński K., 2002, Nasza ziemia - gospodarka globalna, Wydawnictwo Kurpisz, Poznań.

15. Oniszczuk-Jastrząbek A., Gutowski T., 2011, Czynniki wpływające na zwiększenie konkurencyjności pomorskich przedsiębiorstw, Toruń (referat w druku).

16. Otta W. J., 1988, Strategia eksportowa producenta, Wydawnictwo TNOiK, Poznań.

17. Porter M.E., 1985, Competitive Advantage. Creating and Sustaining Superior Performance, „The Free Press", New York.

18. Porter M.E., 1996, Strategia konkurencji. Metody analizy sektorów i konkurentów, PWE, Warszawa.

19. Roszyk-Kowalska G., 2007, Przewaga konkurencyjna w aspekcie kluczowych kompetencji przedsiębiorstwa, www.sgh.waw.pl/katedry/ktz/mf2020/referaty/Przewaga_konkurencyjna_w_aspekcie_kluczowych_kompetencji_przedsiebiorstwa.pdf

20. Stabryła A., 2002, Zarządzanie strategiczne w teorii i praktyce firmy, PWN, Warszawa.

21. Stanienda J., 2006, Determinanty rozwoju i konkurencyjności przedsiębiorstw w regionie, Wydawnictwo Małopolskiej Wyższej Szkoły Ekonomicznej, Tarnów.

22. Stankiewicz M.J., 2000, Istota i sposoby oceny konkurencyjności przedsiębiorstwa, „Gospodarka Narodowa", $\mathrm{nr} 7 / 8$.

23. Stankiewicz M.J., 2002, Konkurencyjność przedsiębiorstwa, Wydawnictwo Dom Organizatora, Toruń.

24. Suszyński C. (red.), 2007, Przedsiębiorstwo. Wartość. Zarządzanie, PWE, Warszawa.

25. Wajda A., 2003, Organizacja i zarządzanie, PWE, Warszawa.

26. Witkowska J., 2005, Zagraniczne źródła innowacji w Polsce [w:] Procesy innowacyjne w polskiej gospodarce, Rada Strategii Społeczno-Gospodarczej przy Radzie Ministrów, Raport nr 26, Warszawa.

27. Wyrwa D., 2006, Mate i średnie przedsiębiorstwa w procesie globalizacji [w:] Integracja a globalizacja. Materiały konferencyjne, J. Rymarczyk, W. Michalczyk (red.), Akademia Ekonomiczna we Wrocławiu, Wrocław.

28. Zorska A., 1998, Ku globalizacji? Przemiany w korporacjach międzynarodowych $i$ w gospodarce światowej, Wydawnictwo Naukowe PWN, Warszawa.

29. Żurek J., 2002, Globalizacja - współczesny kierunek rozwoju gospodarki światowej [w:] Transport morski w gospodarce globalnej, Fundacja Rozwoju Uniwersytetu Gdańskiego, Gdańsk.

30. Żurek J., 2007, Przedsiębiorstwo w systemie społeczno-gospodarczym [w:] Przedsiębiorstwo. Zasady działania, funkcjonowanie, rozwój, J. Żurek (red.), Fundacja Rozwoju Uniwersytetu Gdańskiego, Gdańsk.

31. Żurek J., 2002, Transport morski w gospodarce globalnej, Fundacja Rozwoju Uniwersytetu Gdańskiego, Gdańsk. 


\section{Competitiveness of Enterprises in the Global Economy}

Process of management in the modern world forces enterprises to take many decisions at the strategic level. The ultimate goal of these decisions is to improve the competitiveness of enterprises and the competitiveness of the countries in which they conduct their business. Management of companies imposes a necessity of having in mind the need for the changes - necessary from the perspective of broader competitiveness - as well as ensuring their implementation in shorter time than the competitors can.

It is true that new management conditions pose new challenges for companies and open up new opportunities. But it would be advisable to carry out accurate identification of the factors where the necessary changes should be made first, then implement these changes, so as to be able in future to exploit these factors for companies' development. 